$14 \mid 1990$

Inde

\title{
Le sucre en Inde
}

Systèmes techniques et innovations endogènes

José Muchnik et Roland Treillon

\section{OpenEdition}

Journals

Édition électronique

URL : https://journals.openedition.org/tc/774

DOI : $10.4000 /$ tc. 774

ISSN : 1952-420X

Éditeur

Éditions de l'EHESS

\section{Édition imprimée}

Date de publication : 1 octobre 1990

ISSN : 0248-6016

Référence électronique

José Muchnik et Roland Treillon, « Le sucre en Inde », Techniques \& Culture [En ligne], 14 | 1990, mis en ligne le 16 janvier 2006, consulté le 29 septembre 2022. URL : http://journals.openedition.org/tc/774 ; DOI : https://doi.org/10.4000/tc. 774

Ce document a été généré automatiquement le 29 septembre 2022.

Tous droits réservés 


\section{Le sucre en Inde}

Systèmes techniques et innovations endogènes

José Muchnik et Roland Treillon 